\title{
Analisis Transformasi Spasial Akibat Urban Sprawl di Pinggiran Kota Singaraja, Kabupaten Buleleng
}

\author{
Analysis of Spatial Transformation Due to Urban Sprawl in Suburban of \\ Singaraja City, Buleleng Regency
}

\section{Gede Wyana Lokantara ${ }^{1}$}

Program Studi Perencanaan Wilayah dan Kota, Universitas Terbuka, Tangerang Selatan, Indonesia

\section{Farisa Maulinam Amo}

Program Studi Perencanaan Wilayah dan Kota, Universitas Terbuka, Tangerang Selatan, Indonesia

Artikel Masuk : 3 Mei 2021

Artikel Diterima : 24 Agustus 2021

Tersedia Online : 31 Desember 2021

\begin{abstract}
Abstrak: Perkembangan aktivitas ekonomi yang terjadi di pusat kota apabila sudah jenuh akan mengalami pergerakan menuju ke arah pinggiran kota. Kota Singaraja adalah salah satu wilayah yang mengalami perkembangan menuju ke arah pinggiran kota. Penelitian ini bertujuan untuk menganalisis perkembangan pinggiran Kota Singaraja secara spasial dengan melihat pola perkembangan kotanya akibat pengaruh urban sprawl dan faktor yang menyebabkannya. Pendekatan analisis spasial digunakan dalam penelitian ini untuk menentukan pola perkembangan kota dan menggunakan pendekatan analisis socio-spatial untuk mengidentifikasi faktor penyebab terjadinya urban sprawl di pinggiran Kota Singaraja. Secara makro, Kota Singaraja dan pinggirannya mengalami pola perkembangan spasial berbentuk leap-frog development yang bergerak dari pusat kota menuju wilayah barat dan timur yaitu Desa Bakti Seraga, Kelurahan Banyuasri, dan Kelurahan Banyuning. Faktor yang menyebabkan terjadinya urban sprawl terjadi di pinggiran Kota Singaraja yaitu keinginan yang tinggi dari masyarakat mengubah orientasi kegiatan pertanian menjadi kegiatan ekonomi bersifat komersial dengan membuka toko-toko dan pelayanan jasa untuk memfasilitasi kebutuhan mahasiswa. Faktor pertumbuhan ekonomi tersebut yang mendorong perkembangan spasial di pusat kota dan melewati batas administrasi kota menuju ke wilayah pinggiran Kota Singaraja.
\end{abstract}

Kata Kunci: Kota Singaraja; leap-frog development; pinggiran kota; urban sprawl

Abstract: The development of an economic activity that occurs in the city center when it is saturated will experience a movement towards the outskirts of the city. Singaraja City, one of the areas that are experiencing development towards the outskirts of the city. The study aims to analyze the development of the outskirts of Singaraja City spatially by looking at the pattern of urban development due to the influence of urban sprawl and the factors that cause it. This study was analyzed using a spatial analysis approach to determine the pattern of urban development and using a socio-spatial analysis approach to identify the factors causing

\footnotetext{
${ }^{1}$ Korespondensi Penulis: Program Studi Perencanaan Wilayah dan Kota, Universitas Terbuka, Tangerang Selatan, Indonesia Email: igede-wyana@ecampus.ut.ac.id
} 


\section{Analisis Transformasi Spasial Akibat Urban Sprawl di Pinggiran Kota Singaraja, Kabupaten Buleleng}

urban sprawl on the outskirts of Singaraja City. On a macro level, Singaraja City and its outskirts experience a pattern of spatial development in the form of leap-frog development that moves from the city center to the west and east, namely Bakti Seraga Village, Banyuasri Village, and Banyuning Village. The factor that causes urban sprawl to occur on the outskirts of Singaraja City is the high desire of the community to change the orientation of agricultural activities into commercial economic activities by opening shops and services to facilitate student needs. These economic growth factors encourage spatial development in the city center and beyond the administrative boundaries of the city to the outskirts of Singaraja City.

Keywords: leap-frog development; Singaraja City; suburbs; urban sprawl

\section{Pendahuluan}

Aktivitas pembangunan di berbagai kota di Indonesia menjadi penyebab adanya peningkatan pertumbuhan ekonomi pada wilayah tersebut (Hanief \& Dewi, 2014). Aktivitas masyarakat yang bervariasi dalam kegiatan ekonomi, sosial, dan budaya berpeluang untuk meningkatkan permintaan lahan, akibatnya ketersediaan lahan di Kawasan perkotaan menjadi terbatas (Rohmadiani et al., 2020). Ketersediaan lahan yang terbatas di pusat kota menyebabkan harga tanah menjadi relatif mahal (Putra, 2019). Harga lahan yang mahal dan terbatas menyebabkan kota tidak mampu menampung aktivitas dan keberadaan penghuninya, di satu sisi adanya keterbatasan batas administrasi wilayah perkotaan mengakibatkan terjadi orientasi pembangunan bergerak menuju wilayah pinggiran perkotaan (Pratama \& Ariastita, 2016). Sementara itu, pertumbuhan penduduk berlangsung terus menerus yang menyebabkan arus mobilitas penduduk bergerak menuju wilayah pinggiran kota yang potensial mengalami pertumbuhan ekonomi (Mujiandari, 2014). Transformasi kawasan perkotaan menuju kawasan pinggiran perkotaan menyebabkan terjadinya proses transformasi spasial secara fisik berupa proses densifikasi permukiman dan transformasi sosial ekonomi sebagai bentuk dampak lanjutan dari proses transformasi spasial fisik tersebut (Wahyuningsih et al., 2017). Kondisi kepadatan permukiman yang terjadi di kawasan suburban merupakan bentuk representasi dari kebutuhan ruang yang semakin meningkat di kawasan perkotaan (Giyarsih, 2010).

Menurut Mujiandari (2014), munculnya kawasan permukiman terbangun yang tersebar di wilayah pinggiran kota, yang bersifat tidak teratur dan tidak terintegrasi antara satu sama lain di daerah pinggiran kota memunculkan ruang-ruang kosong baik antarkawasan perumahan maupun antara kawasan perumahan dengan pusat kota. Hal tersebut menjadi ciri khas dari gejala perubahan spasial yang terjadi pada wilayah yang teridentifikasi urban sprawl (Desiyana, 2018). Fenomena perubahan spasial di Kota Singaraja terlihat dari pertambahan penduduk selama 20 tahun. Pertambahan jumlah penduduk ini menyebabkan perubahan orientasi aktivitas pembangunan yang bergerak dari wilayah perkotaan ke wilayah pinggiran Kota Singaraja, Kabupaten Buleleng, Provinsi Bali yang ditandai dengan adanya mobilitas penduduk yang signifikan dan berkembangnya kawasan permukiman di kawasan pinggiran Kota Singaraja. Berdasarkan identifikasi data kependudukan yang berkembang Kota Singaraja pada tahun 2000, 2010, dan 2020 terjadi peningkatan jumlah penduduk yang cukup tinggi dan pertambahan tersebut sebagian besar disebabkan oleh faktor mobilitas penduduk (Gambar 1). Mobilitas pergerakan penduduk yang cukup tinggi akan mempengaruhi terjadinya peningkatan kebutuhan terhadap ruang, adanya perubahan kemampuan sistem transportasi, pembangunan perumahan, dan keberadaan infrastruktur perkotaan yang harus menyentuh sampai ke wilayah luar (Amin Ishak et al., 2018). Hal ini merupakan kondisi awal karakter urban sprawl yang terjadi di pinggiran Kota Singaraja. 


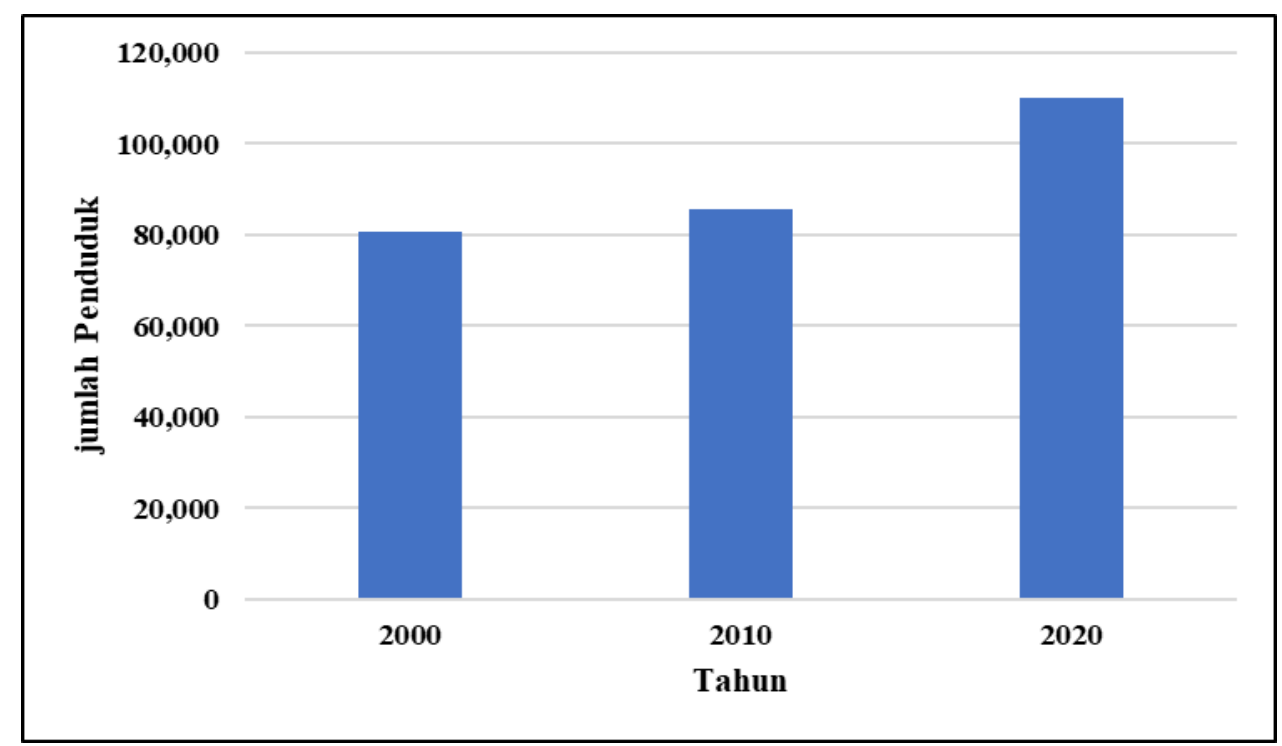

Sumber: BPS Kabupaten Buleleng, 2020

Gambar 1. Pertambahan Penduduk di Kota Singaraja Tahun 2000, 2010, dan 2020

Hal yang menarik dalam kasus perkembangan spasial wilayah Kota Singaraja yaitu karakteristik Kota Singaraja bukan merupakan kawasan ekonomi ataupun aglomerasi industri, melainkan sebagai kota tujuan pendidikan dan pariwisata, dan kasus ini mirip seperti Kota Yogyakarta. Namun perbedaannya adalah Kota Yogyakarta posisinya berdekatan dengan kota-kota besar lainnya seperti Solo, Semarang, dan Magelang yang dapat mempengaruhi perkembangan Kota Yogyakarta (Giyarsih, 2010). Namun untuk kasus Kota Singaraja merupakan kota yang sangat minimum mendapatkan pengaruh dari kota lainnya, karena letaknya tidak langsung mendapat pengaruh dari kota lainnya. Konsentrasi perkembangan sarana dan fasilitas pendidikan membuat para mahasiswa pendatang memilih Kota Singaraja sebagai tujuan pendidikan. Mobilitas migran yang datang secara terus menerus akan berkorelasi dengan perubahan aktivitas ekonomi yang tentunya mengarah pada nonpertanian, yang menyebabkan kebutuhan penggunaan lahan terbangun, seperti pemukiman, lahan komersil, kegiatan sosial untuk mendukung kegiatan di sekitar kampus maupun sekolah. Analisis transformasi spasial beserta faktor penyebab fenomena urban sprawl di pinggiran Kota Singaraja menjadi poin utama yang perlu dikaji, karena karakteristik Kota Singaraja bukan sebagai wilayah pertumbuhan industri, kawasan ekonomi khusus tetapi lebih kepada kota tujuan pendidikan. Perubahan spasial tersebut akan tampak pada desa atau kelurahan yang mengalami perubahan fisik seperti perkembangan jaringan jalan, tata guna lahan, dan aktivitas ekonomi yang mencerminkan sifat kekotaan yang terpengaruh akibat kegiatan pusat kota (Desiyana, 2018). Penelitian ini bertujuan untuk menganalisis perkembangan pinggiran Kota Singaraja secara spasial dengan melihat pola perkembangan kotanya akibat pengaruh urban sprawl dan faktor yang menyebabkannya..

\section{Metode Penelitian}

Penelitian ini merupakan penelitian yang menggunakan mix method yang menekankan pada identifikasi transformasi kawasan perkotaan Singaraja beserta pola perubahan spasial, sosial, maupun ekonomi. Untuk mengidentifikasi transformasi kawasan 


\section{Analisis Transformasi Spasial Akibat Urban Sprawl di Pinggiran Kota Singaraja, Kabupaten Buleleng}

perkotaan Singaraja dilakukan dengan melihat sejarah perkembangan Kota Singaraja dari periode waktu secara time series. Analisis kuantitatif dilakukan dengan analisis statistik deskriptif, analisis spasial, dan analisis skoring. Analisis statistik deskriptif digunakan untuk mendeskripsikan hasil dari kompilasi data dan data hasil pembacaan software Quantum GIS dan google earth pro, dengan memberikan pemaknaan berdasarkan perspektif spasial yang diamati (Rahman et al., 2021). Analisis spasial dengan software Quantum GIS berfungsi untuk mengidentifikasi pola pertumbuhan dan percepatan kota dengan data berupa citra kawasan Kota Singaraja, terkait jarak, kepadatan lahan, jaringan jalan dan analisis pola perubahan spasial. Analisis skoring sangat penting untuk menentukan tipologi/tingkat urban sprawl sesuai dengan variabel perkembangan urban sprawl yang sudah ditentukan.

Sementara faktor-faktor yang menyebabkan terjadinya perubahan sosial dan ekonomi di kawasan pinggiran Kota Singaraja akan dianalisis menggunakan pendekatan socio-spatial (Saputra et al., 2019). Pendekatan socio-spatial ini menekankan pada strategi untuk menganalisis ragam fenomena dan dinamika yang terjadi di wilayah pinggiran Kota Singaraja, terutama yang masih dalam bentuk proses transformasi kegiatan yang mencerminkan sifat kekotaan. Teknik pengumpulan data yang digunakan adalah dengan memberikan kuesioner terhadap responden yang memiliki identitas sebagai penduduk pendatang atau yang memicu terjadinya urban sprawl. Model analisis perkembangan urban sprawl di pinggiran Kota Singaraja digambarkan pada Gambar 2.

Data spasial yang akan menggambarkan perkembangan kawasan di Kota Singaraja dan wilayah pinggiran adalah analisis perkembangan kepadatan permukiman di Kota Singaraja dan kawasan pinggiran Kota Singaraja. Selanjutnya dilakukan analisis pola perkembangan spasial baik yang memiliki karakter leap-frog, ribbon development akan dianalisis berdasarkan hasil perhitungan jarak dari pusat bangunan maupun permukiman baru sampai dengan pusat permukiman lama pada setiap kecamatan pada Kota Singaraja, yang teridentifikasi sprawl. Tipe ribbon development tersebut dalam perkembangan urban sprawl ini dianggap merugikan, tidak estetik dan tidak efisien (Festus et al., 2020).

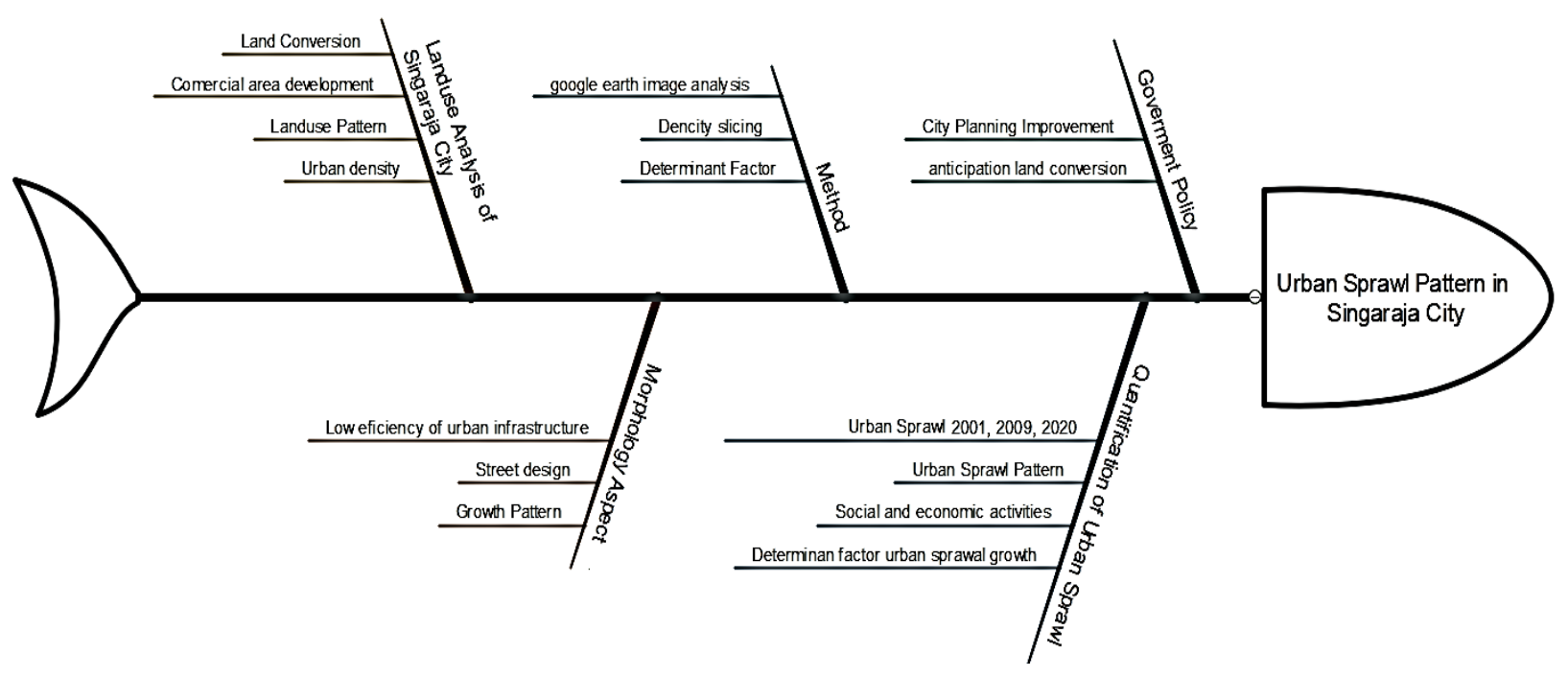

Gambar 2. Model Analisis Perkembangan Fenomena Urban Sprawl di Pinggiran Kota Singaraja 


\section{Hasil dan Pembahasan}

\section{Analisis Transformasi Spasial Akibat Urban Sprawl Pinggiran Kota Singaraja}

Perkembangan fenomena urban sprawl pada perkembangan perkotaan yang terjadi di Kota Singaraja mengalami proses perubahan dalam kurun waktu yang berbeda-beda. Hal ini terutama dapat terjadi di bagian-bagian wilayah tertentu, terutama di daerah pinggiran kota. Perubahan tata ruang di Kota Singaraja terdiri dari penggunaan lahan terbangun yang terlihat pada perubahan penggunaan lahan untuk membangun kawasan pemukiman. Peningkatan jumlah penduduk di Kota Singaraja juga mempengaruhi kondisi penggunaan lahan. Peningkatan jumlah penduduk ini berbanding lurus dengan aktivitas yang dihasilkan sehingga membutuhkan lahan untuk menampung aktivitas yang terjadi. Lahan yang semula nonterbangun berubah menjadi terbangun, seperti kawasan pemukiman dan komersial mendominasi kawasan Kota Singaraja. Hasil analisis menunjukkan bahwa terdapat penggunaan lahan terbangun di Kota Singaraja, seperti adanya pengembangan kawasan komersial berupa kompleks pertokoan, mall dan fasilitas publik serta deretan ruko di kawasan pemukiman. Berdasarkan analisis data google earth tahun 2010, 2015, dan 2020, terdapat perubahan penggunaan lahan di beberapa lokasi di peri urban Kota Singaraja. Perubahan penggunaan lahan digunakan untuk kawasan pemukiman. Perubahan signifikan terjadi di kawasan Desa Bakti Seraga yang meningkat dari 37 ha pada tahun 2010 menjadi 280 ha pada tahun 2020 dan Desa Banyuasri meningkat dari 26 ha pada tahun 2010 menjadi 312 ha pada tahun 2020. Perubahan ini terjadi karena pembangunan perumahan oleh pengembang dalam menyediakan tempat tinggal bagi masyarakat, sehingga membuat lahan pertanian diubah menjadi lahan terbangun.

Perubahan fungsi lahan terbuka, seperti sawah dan tegalan, tidak secara langsung mengubah fungsi menjadi lahan maju dan berkembang serta lahan untuk kegiatan ekonomi komersial (Resnik, 2010). Pada umumnya persawahan dan tegalan dibuka dan untuk sementara diubah menjadi lahan kosong yang siap dibangun atau dibuat kavling tanah. Sementara itu, wilayah Desa Banyuning mengalami perubahan tata ruang yang paling kompleks dibandingkan dengan wilayah lainnya, hal ini terlihat dari semakin melebarnya ragam aktivitas penduduk di wilayah desa ini yang hampir menyerupai pusat aktivitas perkotaan. Lebih jelasnya dapat dilihat pada Gambar 3.

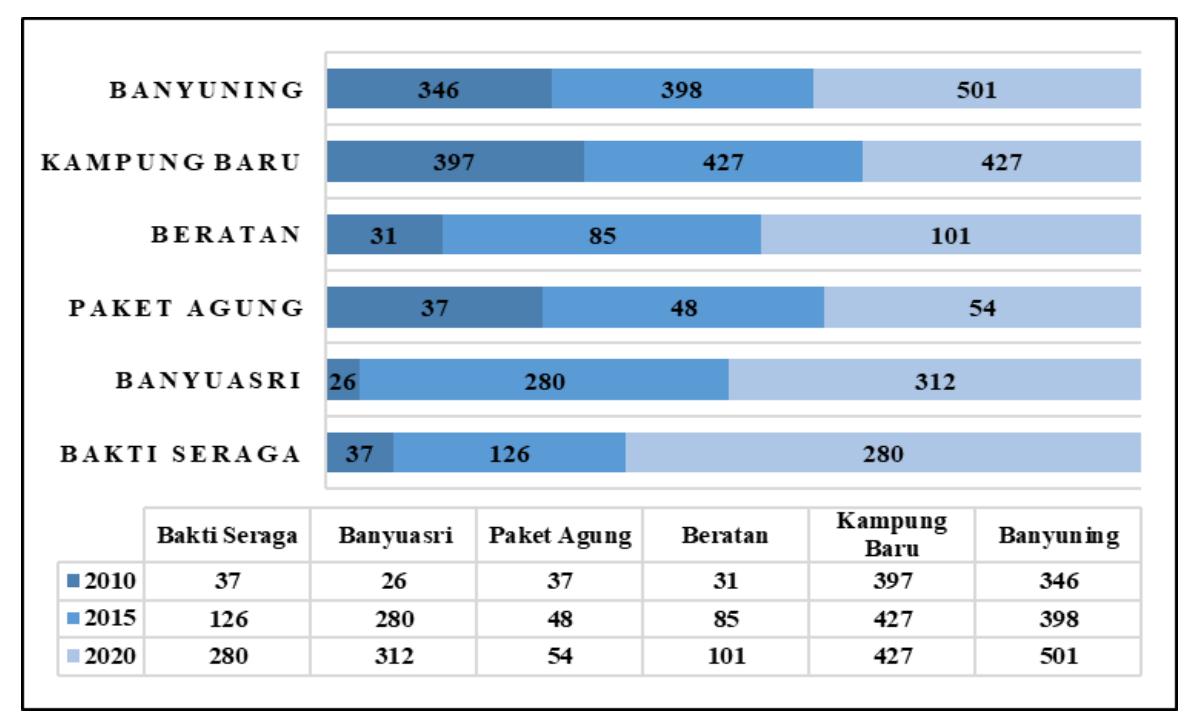

Gambar 3. Perkembangan Luas Permukiman di Pinggiran Kota Singaraja Tahun 2010, 2015, 2020 
Hasil identifikasi perkembangan luas permukiman analisis spasial Kota Singaraja menunjukkan perbedaan yang cukup pesat selama kurun waktu 20 tahun. Tutupan lahan kawasan kota mengalami pertumbuhan yang semakin meningkat sehingga menyebabkan perluasan kawasan terbangun pada di wilayah pinggiran yang dekat dengan pusat Kota Singaraja. Perkembangan spasial perluasan terbangun ini menunjukkan bahwa aktivitas perkotaan di kawasan Kota Singaraja merupakan kawasan yang berkembang pesat dan menyebar ke Peri Urban Kota Singaraja yang dipengaruhi oleh tingginya jumlah permukiman akibat meningkatnya tekanan kebutuhan perumahan bagi masyarakat dan penggunaan lahan untuk komersial atau kegiatan ekonomi (Gambar 4). Berdasarkan hasil analisis pemetaan spasial perkembangan Kota Singaraja, telah terjadi perubahan signifikan yang menjalar ke wilayah Desa Banyuning, Desa Bakti Seraga dan Desa Banyuasri. Ketiga wilayah desa tersebut terletak sangat dekat dengan pusat Kota Singaraja.

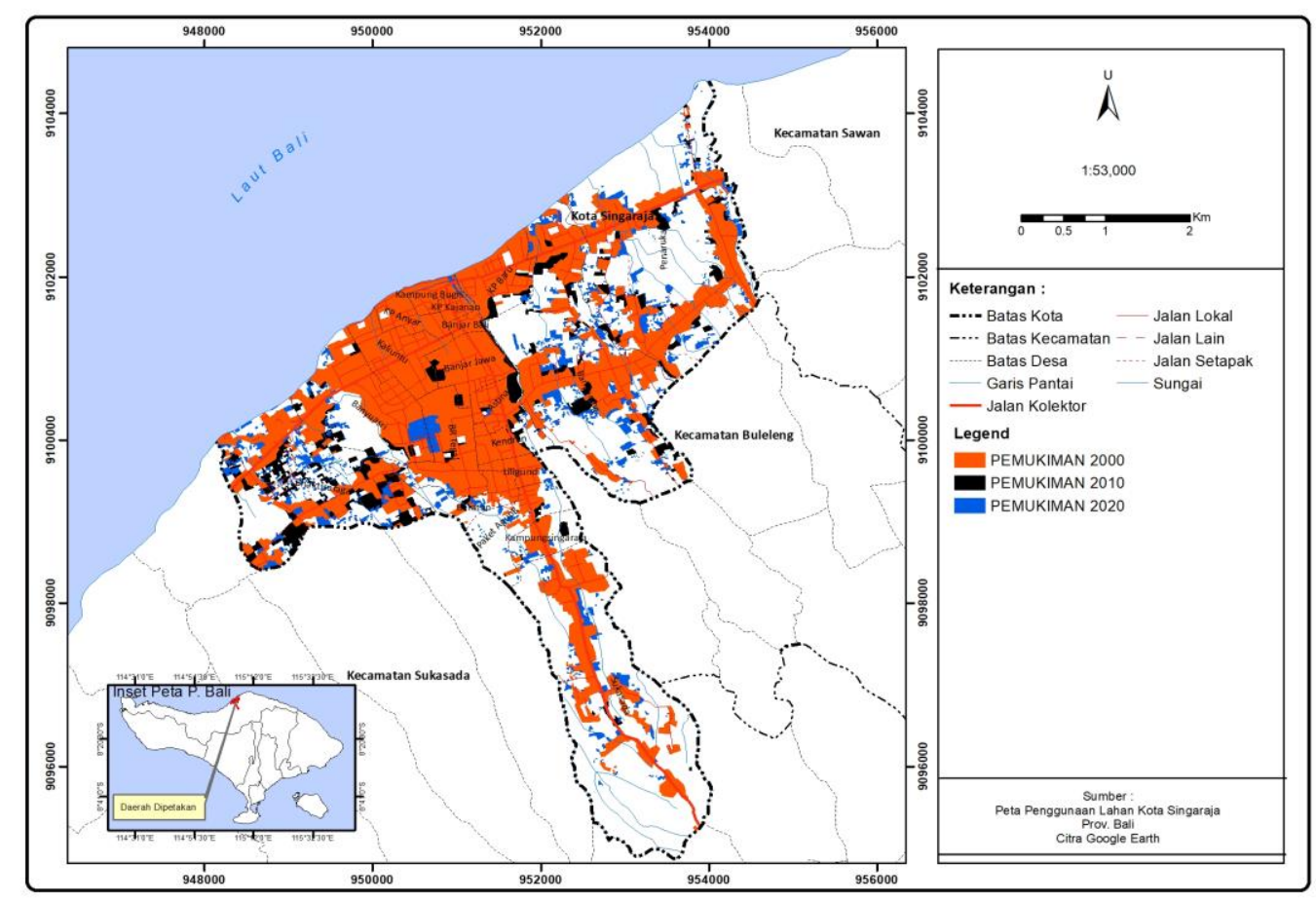

\section{Gambar 4. Analisis Perkembangan Permukiman di Pinggiran Kota Singaraja}

Berdasarkan hasil analisis spasial tentang perkembangan urban sprawl di Kota Singaraja, tipologi perkembangan fisik pinggiran kota Singaraja sudah menunjukkan sifat kekotaan terutama pada wilayah barat yaitu Kelurahan Bakti Seraga yang berkembang sebagai kawasan permukiman dan sebelah timur yaitu Kelurahan Banyuning berkembang sebagai kawasan ekonomi. Perkembangan tersebut ditandai dengan adanya peningkatan aktivitas penduduk yang menggunakan lahan untuk mengembangkan kegiatan komersial berupa usaha pertokoan, fasilitas umum, dan semakin tingginya intensitas pengembangan jaringan jalan. Berdasarkan hasil analisis, tipe urban sprawl yang terjadi di kawasan Peri Urban Kota Singaraja termasuk dalam tipe perkembangan leap-frog, ciri-cirinya dapat dilihat dari beberapa pola perkembangan kota yang terjadi secara sporadis di luar kawasan binaan utama dan kawasan pengembangan baru yang terbentuk berada di tengah kawasan yang belum berkembang, munculnya kawasan terbangun baru yang tidak terintegrasi dengan kawasan terbangun utama dan diperantarai oleh lahan terbelakang yang biasanya merupakan lahan pertanian produktif (Polidoro et al., 2012). Tipe urban sprawl Kota 
Singaraja yang bergerak ke arah timur dan barat dipicu oleh perkembangan infrastruktur perkotaan seperti kawasan komersial, pelayanan pendidikan, perumahan, dan pelayanan kesehatan, seperti yang terjadi di Desa Banyuning dan Desa Bakti Seraga.

Transformasi spasial yang terjadi di Kota Singaraja mengakibatkan perubahan yang cukup signifikan terutama merembet ke Desa Banyuning, Desa Bakti Seraga, dan Desa Banyuasri. Ketiga kawasan tersebut lokasinya sangat dekat dengan pusat Kota Singaraja. Karakteristik sprawl yang telah dihitung berdasarkan jumlah kawasan terbangun dan penggunaan lahan komersial, teridentifikasi bahwa arah perkembangan sprawl tertinggi mendapatkan hasil total skor tingkat urban sprawl. Setelah mendapatkan total skor untuk masing-masing kelurahan yang teridentifikasi sprawl, selanjutnya diklasifikasikan tipologi perkembangan wilayah pinggiran yang sudah mendekati gejala menyerupai pusat Kota Singaraja, yaitu wilayah bagian timur masuk kawasan terpengaruh utama yang terdiri dari Desa Banyuning dan Kelurahan Kampung Baru. Hal ini dibuktikan dengan berkembangnya aktivitas perkotaan seperti kawasan hunian seperti perumahan, tumbuhnya kawasan komersial, fasilitas umum, jaringan jalan. Secara makro, perembetan fisik kekotaan pada wilayah pinggiran Kota Singaraja, berkembang dengan tipe leap-frog development. Menurut (Wagistina \& Antariksa, 2019) tipe ini menunjukkan bentuk perkembangan sifat kekotaan yang terjadi secara sporadis di luar daerah terbangun utamanya dan daerah pembangunan baru yang terbentuk berada di tengah daerah yang belum terbangun (Gambar 5). Bentuk perkembangan ini merupakan bentuk yang paling dominan terjadi terhadap lahan-lahan pertanian di daerah pinggiran kota dibandingkan dengan bentuk lainnya.

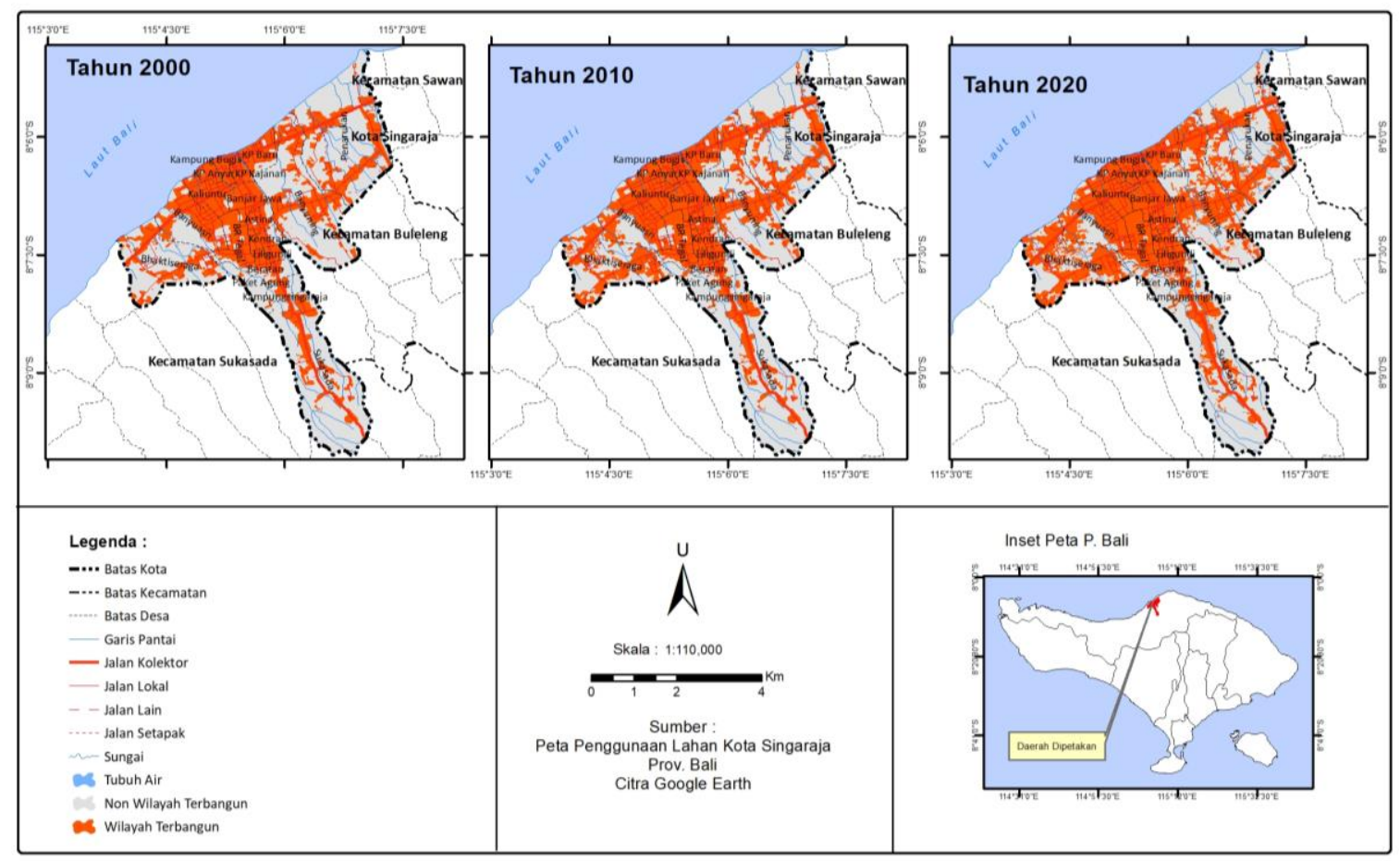

Gambar 5. Peta Perkembangan Lahan di Pinggiran Kota Singaraja Tahun 2000-2020

Perkembangan ini terjadi di wilayah pinggiran Kota Singaraja karena beberapa kawasan terbangun baru yang muncul, tidak menyatu dengan daerah terbangun utama 
antara lahan-lahan belum terbangun yang biasanya merupakan kawasan pertanian. Dalam konteks mikro wilayah seperti Desa Bakti Seraga merupakan wilayah yang dominan berkembang dengan tipe leap-frog development dan terlihat dari perkembangan lahan terbangun terjadi berpencar dan tumbuh di tengah lahan pertanian. Berdasarkan kategori daerah pinggiran kota, Desa Bakti Seraga termasuk dalam kategori potential urban, yaitu kawasan dengan ciri utamanya masih rural yaitu berkarakteristik desa tetapi mempunyai peluang besar untuk lambat laun menjadi kawasan urban. Selanjutnya Kelurahan Banyuning termasuk dalam kategori wilayah semi urban dengan perkembangan pola spasial campuran antara leap-frog dan ribbon development yang dipengaruhi oleh adanya pembangunan kawasan permukiman baru yang dibangun di tengah lahan pertanian dan terdapat pengembangan infrastruktur jalan, dan kegiatan komersial pertokoan. Pola spasial Kelurahan Banyuning memiliki pola ribbon development (Nurrokhman, 2019). Sementara wilayah lain yang terdapat dalam pinggiran Kota Singaraja yaitu Kelurahan Banyuasri termasuk dalam perkembangan predominantly urban, yaitu perkembangan pola spasialnya dipengaruhi oleh perkembangan infrastruktur dan fasilitas kota seperti terminal, pasar dan pusat kegiatan ekonomi lainnya sehingga menyebabkan pola spasial Banyuasri memiliki pola ribbon development. Hal ini ditunjukkan dengan munculnya alih fungsi lahan yang sangat signifikan menuju peri urban Kota Singaraja yang menjadi kawasan pemukiman baru (Arifin et al., 2018).

\section{Analisis FaktorPenyebab Terjadinya Urban Sprawl di Pinggiran Kota Singaraja}

Menurut Giyarsih (2010) fenomena urban sprawl yang terjadi di Kota Yogyakarta mengakibatkan terjadinya tranformasi penggunaan lahan dari karakteristik pertanian menjadi penggunaan lahan nonpertanian yang mengubah pola spasial Kota Yogyakarta sampai ke arah pinggiran kota. Terjadinya alih fungsi lahan pertanian menjadi kegiatan nonpertanian tersebut menyebabkan terjadinya proses densifikasi permukiman dan kawasan terbangun lainnya pada akhirnya menyebabkan terjadinya perubahan secara sosial, maupun ekonomi. Kota Singaraja dalam hal ini juga memiliki karakteristik spasial yang sama dengan Kota Yogyakarta yaitu mengalami pertumbuhan pusat kota sampai ke arah pinggiran kota yang bergerak ke arah timur dan barat dengan pola yang berbeda (Gambar 6). Kota Singaraja dalam kasus ini sebagian wilayahnya merupakan wilayah semi urban, yang disebabkan oleh banyaknya pergerakan penduduk menuju ke Kota Singaraja untuk bersekolah ataupun kuliah karena di Kota Singaraja banyak tersedia sekolah maupun universitas khususnya Universitas Pendidikan Ganesha, Singaraja yang menjadi tujuan para migran untuk memperoleh pendidikan. Selain itu banyak migran pendatang yang membuka usaha komersial dan memilih tinggal di wilayah pinggiran Kota Singaraja. Desa Bakti Seraga, Kelurahan Banyuasri, dan Kelurahan Banyuning memiliki karakteristik wilayah semi urban yang sedang mengalami pertumbuhan, akibat adanya perubahan orientasi aktivitas sosial maupun ekonomi mengalami transformasi spasial yang cukup pesat karena masih banyak menyediakan ruang terbuka seperti sawah maupun tegalan yang sewaktu-waktu dapat dikembangkan menjadi kawasan terbangun untuk kebutuhan aktivitas penduduk lokal maupun pendatang terutama dalam menyediakan kebutuhan hunian maupun aktivitas komersial (Jain et al., 2016).

Aktivitas penduduk di wilayah pinggiran Kota Singaraja kawasan pinggiran Kota Singaraja yang menjadi faktor determinan penyebab terjadinya urban sprawl di peri urban Kota Singaraja yaitu masyarakat sekitar lebih memilih untuk mengubah orientasi kegiatan ekonomi sebesar 96,67\% yaitu dengan memilih untuk membuka toko, warung yang menyediakan kebutuhan pelajar dan mahasiswa (Gambar 7). Hasil analisis temuan ini sangat sesuai dengan pendapat Wahyuningsih et al. (2017) yang menjelaskan bahwa faktor yang mendorong terjadinya transformasi socio-spatial di wilayah peri urban yaitu ditandai dengan adanya pertumbuhan ekonomi yang melintasi batas-batas administrasi perkotaan 
menuju ke arah luar dengan pola aktivitas yang beragam dan tidak teratur. Kondisi tersebut menyebabkan pergerakan penduduk secara cepat dan terjadi perluasan lahan terbangun di kawasan pinggiran kota yang saling berdekatan sehingga menyebabkan berkembangnya koridor-koridor yang terintegrasi (Prastowo, 2016).

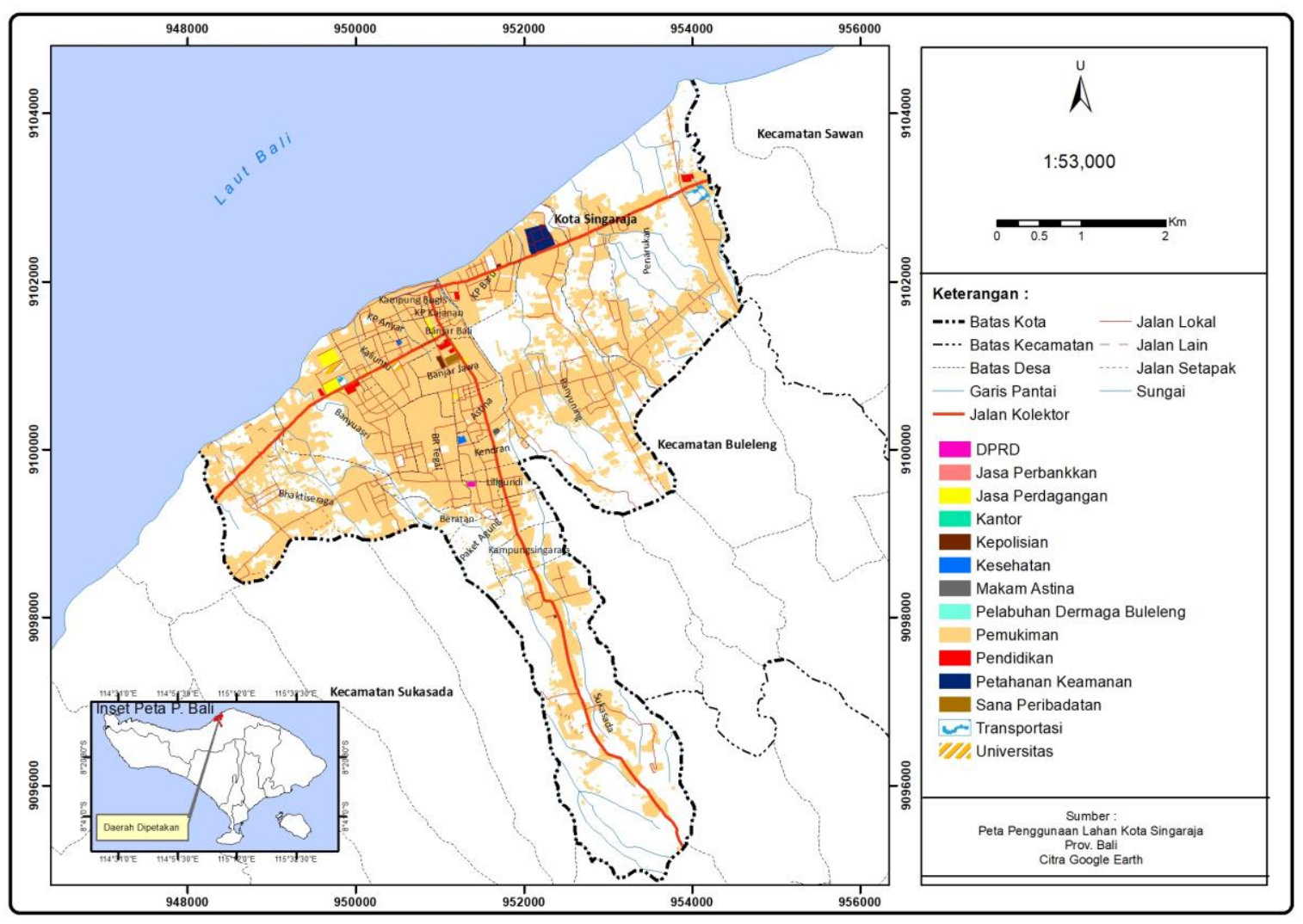

Gambar 6. Kepadatan Lahan di Pinggiran Kota Singaraja Tahun 2021

Peningkatan perubahan penggunaan lahan untuk lahan terbangun paling signifikan terjadi di Kelurahan Banyuning dan Bakti Seraga, karena kedua wilayah tersebut merupakan wilayah pusat pertumbuhan dan kegiatan ekonomi yang ada di Kota Singaraja. Selain sebagai wilayah pusat pertumbuhan ekonomi, transformasi spasial tersebut terjadi akibat perluasan aktivitas pusat kota yang telah menyebar ke wilayah pinggiran Kota Singaraja. Faktor utama yang mempengaruhi transformasi tersebut karena mudahnya memperoleh lahan untuk dijadikan kawasan permukiman baru dan kegiatan ekonomi . Berdasarkan hasil analisis pemetaan spasial perkembangan Kota Singaraja, maka terjadi perubahan signifikan yang menjalar ke wilayah pinggiran, yang ditandai dengan makin tingginya intensitas pembangunan dan pelebaran jalan. Secara geografis jarak antara pusat kota dengan wilayah pinggiran Kota Singaraja sangat dekat, hal ini juga yang menjadi pengaruh bahwa semakin cepatnya transformasi perubahan fisik, sosial dan ekonomi yang terjadi di wilayah pinggiran kota.

Penduduk pendatang yang tinggal di pinggiran Kota Singaraja menampilkan aktivitas kehidupan perkotaan (Harmadi \& Yudhistira, 2008). Gaya hidup pendatang ini secara tidak langsung menjadi acuan bagi penduduk lokal yang lambat laun mengikuti pola aktivitas kehidupan penduduk pendatang. Penduduk setempat juga menjadi masyarakat yang konsumtif, dan mengutamakan pertimbangan materialistis dalam berbagai pengambilan 
keputusan. Kehidupan penduduk pendatang mengutamakan kegiatan komersial seperti menyewakan rumah kos, membangun toko, ruko untuk berjualan dan bentuk jasa lainnya untuk melayani masyarakat sekitar dan aktivitas terssebut telah merubah penduduk lokal yang mayoritas bekerja sebagai petani bekerja di sektor nonpertanian.

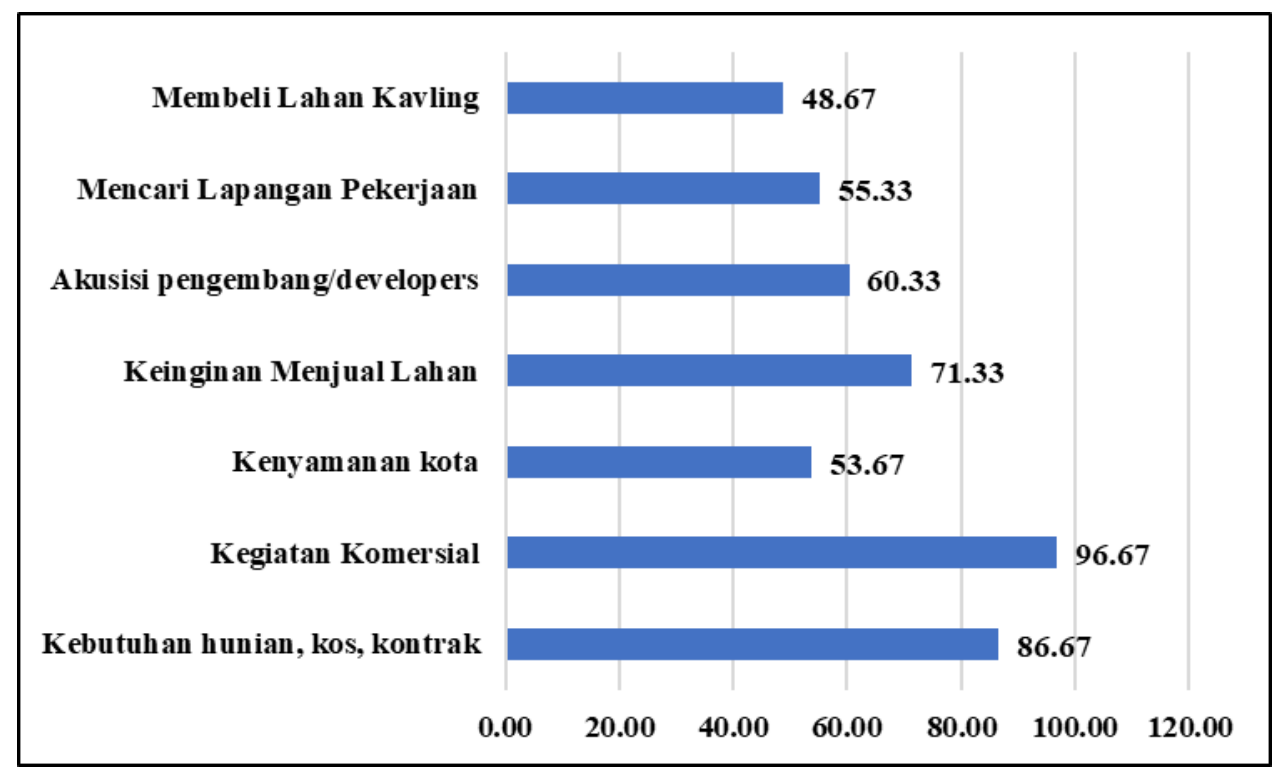

\section{Gambar 7. Hasil Survei Faktor Penyebab Urban Spraw/di Pinggiran Kota Singaraja}

Perkembangnya spasial pusat Kota Singaraja menuju ke arah pinggiran kota menyebabkan karakteristik aktivitas sosial ekonomi masyarakat wilayah pinggiran Kota Singaraja yang sifatnya bervariasi. Adanya orientasi perubahan mata pencaharian masyarakat di daerah pinggiran kota menyebabkan menurunya produksi pangan karena berkurangnya petani untuk dalam menggarap lahan pertanian yang disebabkan oleh banyaknya masyarakat petani yang berubah orientasi menjadi penyedia jasa maupun melakukan kegiatan non pertanian lainnya. Berdasarkan hasil survei, aktivitas ekonomi penduduk di Desa Bakti Seraga mengalami transformasi yaitu sekitar 80,60\% responden menyatakan yang dulunya petani saat ini memilih menjadi berjualan toko kelontong, makanan bahkan menyediakan sewa kos dan rumah kontrakan. Sedangkan di wilayah lainnya seperti Kelurahan Banyuning mengalami transformasi tinggi karena sekitar 85,25 $\%$, Kelurahan Banyuasri sebesar 88,15\%, hal tersebut disebabkan oleh penggunaan lahan bukan lagi digunakan untuk kegiatan pertanian namun sebagai sewa kos dan kontrakan, membuka usaha fotocopy, makanan dan jasa printing. Peningkatan transformasi akomodasi lainnya terlihat dengan adanya penambahan minimarket di beberapa titik di setiap wilayah pinggiran Kota Singaraja, hal tersebut disebabkan oleh Desa Bakti Seraga, Kelurahan Banyuning, dan Kelurahan Banyuasri merupakan kawasan tujuan bermukim bagi penduduk pendatang, sehingga dengan membangun beberapa minimarket membuat akses mencari kebutuhan hidup semakin dekat.

Selain itu faktor lain yang menyebabkan terjadinya urban sprawl di wilayah pinggiran Kota Singaraja adalah harga lahan yang lebih murah dan ketersediaan lahan yang cukup luas dengan skor mencapai $71,33 \%$. Menjual lahan pertanian merupakan jalan pintas bagi keluarga petani untuk mengikuti gaya hidup perkotaan, atau sekedar untuk memenuhi keinginan anak dan keluarga, yang seringkali bahkan tidak dibutuhkan oleh mereka. Dampak negatif sekunder dari masalah ekonomi ini adalah hilangnya pekerjaan sebagai 
petani dan produktivitas lahan. Keberadaan desa-desa yang berada di daerah pinggiran kota dilihat dari pengaruh fisik keberadaan aktivitas pusat Kota Singaraja, mendorong semakin cepatnya perubahan kegiatan ekonomi masyarakat di daerah pinggiran kota seperti terbangunnya kawasan perumahan baru, mall, sarana pendidikan dan jaringan jalan (Tabel 1). Hal ini menyebabkan keberadaan kawasan pinggiran Kota Singaraja tidak dapat dipisahkan dari aktivitas pembangunan karena posisi pusat kota dekat dengan aktivitas perkotaannya, tentu saja secara cepat akan memberikan perubahan struktur aktivitas penduduk di pinggiran Kota Singaraja. Faktor-faktor tersebut mendorong tahap transformasi kawasan Kota Singaraja akibat pertumbuhan ekonomi yang mendorong perkembangan spasial dari pusat kota ke kawasan peri urban. Kondisi ini menyebabkan berkembangnya koridor-koridor baru berupa pembangunan infrastruktur dan jaringan jalan menuju pinggiran kota yang mendorong pertumbuhan baru di sepanjang akses sehingga menjadi kawasan perluasan kota (Mouratidis \& Poortinga, 2020).

Tabel 1. Perubahan Aktivitas Ekonomi di Pinggiran Kota Singaraja Tahun 2021

\begin{tabular}{lrc}
\hline Desa/Kelurahan & Persentase $\mathbf{( \% )}$ & Keterangan \\
\hline Bakti Seraga & 80,60 & Sedang \\
Banyuning & 85,25 & Tinggi \\
Banyuasri & 88,15 & Tinggi \\
Paket Agung & 79,90 & Sedang \\
Kampung Singaraja & 77,65 & Sedang \\
Sukasada & 58,15 & Rendah \\
\hline
\end{tabular}

Dampak urban sprawl di kawasan pinggiran Kota Singaraja menyebabkan banyak ruas jalan dan ruas jalan menjadi lebih panjang karena komposisi fungsi lahan yang berjauhan untuk dapat diakses dengan berjalan kaki (Tappu, 2014). Lebih banyak jalan berarti lebih banyak kendaraan sehingga menyebabkan kemacetan yang tinggi sehingga dapat menimbulkan pencemaran udara di wilayah pinggiran Kota Singaraja. Disi lain kebijakan pemerintah Kota Singaraja juga belum dapat menyediakan pilihan angkutan umum yang sesuai standar, sehingga menyebabkan kualitas angkutan umum kurang memadai dan masyarakat lebih banyak menggunakan kendaraan pribadi. Efek sampingnya adalah polusi udara yang tinggi dan buruknya kualitas lingkungan, khususnya kualitas udara. Di sisi lain semakin padatnya permukiman di kawasan perkotaan akan menyebabkan munculnya permukiman kumuh, turunnya kualitas kesehatan lingkungan. Dampak lingkungan urban sprawl tidak selalu buruk apabila mampu ditangani dengan strategi dan kebijakan yang tepat dan efisien (Follmann et al., 2021). Penerapan smart growth merupakan alternatif pilihan untuk mengurangi kerusakan lingkungan. Pemerintah Kota Singaraja sebagai pemegang kebijakan harus dapat merencanakan dan mengendalikan pembangunan kota. Penata kota bekerjasama dengan pemerintah dan masyarakat menjadikan lingkungan kota lebih layak huni (Ighravwe et al., 2020).

\section{Kesimpulan}

Kota Singaraja, salah satu wilayah di Provinsi Bali yang mengalami perkembangan perkotaan dan terpengaruh fenomena urban sprawl yang bergerak dari pusat kota menuju ke arah timur dan ke arah barat dengan membentuk pola umum leap-frog development. Tipe leap-frog mengubah lahan pertanian secara acak dan dalam skala yang tidak terlalu besar, akan tetapi secara konsisten mengubah satu per satu fungsi tata guna lahan pertanian menjadi lahan terbangun. Aktivitas ekonomi penduduk di Kelurahan Banyuning dan Bakti Seraga mengalami transformasi cukup signifikan, sebanyak $80-85 \%$ responden 


\section{Analisis Transformasi Spasial Akibat Urban Sprawl di Pinggiran Kota Singaraja, Kabupaten Buleleng}

menyatakan yang dulunya petani saat ini memilih menjadi berjualan toko kelontong, warung makanan bahkan menyediakan sewa kos dan rumah kontrakan akibat kebutuhan penduduk pendatang yang semakin tinggi. Peningkatan transformasi akomodasi lainnya terlihat dengan adanya penambahan minimarket di beberapa titik di setiap wilayah pinggiran Kota Singaraja. Melalui hasil penelitian ini fenomena urban sprawl yang tidak dikelola dengan baik akan menyebabkan buruknya kualitas lingkungan, baik kualitas udara maupun air. Namun, urban sprawl dapat diantisipasi dengan penerapan smart growth sebagai alternatif pilihan untuk mengurangi kerusakan lingkungan. Pemerintah Kota Singaraja sebagai pemegang kebijakan harus dapat merencanakan dan mengendalikan tata ruang akibat urban sprawl khususnya yang berkaitan dengan manajemen lingkungan.

\section{Daftar Pustaka}

Amin Ishak, R., Trisutomo, S., Wikantari, R., \& Harisah, A. (2018). Socio-spatial typology in Karanrang Island. SHS Web of Conferences, 41. doi:10.1051/shsconf/20184103001.

Arifin, S., Mukhoriyah, N., \& Yudhatama, D. (2018). Analysis of land use spatial pattern change of town development using remote sensing. International Journal of Remote Sensing and Earth Sciences (IJReSES), 15(1), 93-102. doi:10.30536/j.jireses.2018.v15.a2795.

Badan Pusat Statistik (BPS) Kabupaten Buleleng. (2020). Kabupaten Buleleng dalam angka tahun 2020. Buleleng: Badan Pusat Statistik.

Desiyana, I. (2018). Urban sprawl dan dampaknya pada kualitas lingkungan studi kasus di DKI Jakarta dan Depok, Jawa Barat. Jurnal Komunikasi Visual, 9(2), 16-24. doi:10.31937/ultimart.v9i2.745.

Festus, I. A., Omoboye, I. F., \& Andrew, O. B. (2020). Urban sprawl: Environmental consequence of rapid urban expansion. Malaysian Journal of Social Sciences and Humanities (MJSSH), 5(6), 110-118. doi:10.47405/mjssh.v5i6.411.

Follmann, A., Willkomm, M., \& Dannenberg, P. (2021). As the city grows, what do farmers do? A systematic review of urban and peri-urban agriculture under rapid urban growth across the Global South. Landscape and Urban Planning, 215. doi:10.1016/j.landurbplan.2021.104186.

Giyarsih, S. R. (2010). Pola spasial transformasi wilayah di koridor Yogyakarta-Surakarta. Forum Geografi, 24(1), 28-38. doi:10.23917/forgeo.v24i1.5013.

Hanief, F., \& Dewi, S. P. (2014). Pengaruh urban sprawl terhadap perubahan bentuk Kota Semarang ditinjau dari perubahan kondisi fisik Kelurahan Meteseh Kecamatan Tembalang. Ruang, 2(1), 341-350.

Harmadi, S. H. B., \& Yudhistira, M. (2008). Analisis arah pergérakan aktivitas ekonomi jakarta terhadap daerah sekitarnya dengan menggunakan pendekatan urban sprawl. Jurnal Ekonomi dan Pembangunan Indonesia, 9(1), 71-92. doi:10.21002/jepi.v9i1.149.

Ighravwe, D. E., Oke, S. A., Aikhuele, D., \& Ojo, A. (2020). An optimisation approach to road sanitation workforce planning using differential evolution. Journal of Urban Management, 9(4), 398-407. doi:10.1016/j.jum.2020.06.004.

Jain, M., Dimri, A. P., \& Niyogi, D. (2016). Urban sprawl patterns and processes in delhi from 1977 to 2014 based on remote sensing and spatial metrics approaches. Earth Interactions, 20(14), 1-29. doi:10.1175/EI-D-15-0040.1.

Mouratidis, K., \& Poortinga, W. (2020). Built environment, urban vitality and social cohesion: Do vibrant neighborhoods foster strong communities? Landscape and Urban Planning, 204. doi:10.1016/j.landurbplan.2020.103951.

Mujiandari, R. (2014). Perkembangan urban sprawl Kota Semarang pada wilayah Kabupaten Demak Tahun 2001-2012. Jurnal Wilayah dan Lingkungan, 2(2), 129-142. doi:10.14710/jwl.2.2.129-142.

Nurrokhman, A. (2019). Urban sprawl di indonesia dan kegagalan implementasi kebijakan perlindungan lahan pertanian pangan berkelanjutan. Seminar Nasional "Dinamika Permukiman dan Pembangunan Wilayah di Indonesia" yang diselenggarakan oleh Departemen Geografi Pembangunan, Fakultas Geografi Universitas Gadjah Mada, Yogyakarta, 16 Agustus 2019 (pp 1-14). doi:10.31227/osf.io/taj8c.

Polidoro, M., Lollo, J. A. de, \& Barros, M. V. F. (2012). Urban sprawl and the challenges for urban planning. 
Journal of Environmental Protection, 3(9), 1010-1019. doi:10.4236/jep.2012.39117.

Prastowo, P. (2016). Analisis pengaruh pertumbuhan ekonomi terhadap penggunaan lahan perkotaan pendekatan spatial econometrics: Studi kasus perkotaan DIY, 2011. Jurnal Ekonomi \& Studi Pembangunan, 171), 22-30. doi:10.18196/jesp.17.1.2458.

Pratama, I. P. P. A., \& Ariastita, P. G. (2016). Faktor-faktor pengaruh ukuran urban compactness di Kota Denpasar, Bali. Jurnal Teknik ITS, 5(1), 6-11.

Putra, G. A. (2019). "Socio spatial approach" sebagai metode analisa ruang publik sosial sebagai dinamika kota yang terbentuk dari habitus aktor marginal di era industri 4.0 Seminar Nasional Infrastruktur Berkelanjutan 2019 Era Revolusi Industri 4.0 Teknik Sipil dan Perencanaan, 131-136.

Rahman, Md. H., Islam, Md. H., \& Neema, M. N. (2021). GIS-based compactness measurement of urban form at neighborhood scale: The case of Dhaka, Bangladesh. Journal of Urban Management, March 2020. doi:10.1016/j.jum.2021.08.005.

Resnik, D. B. (2010). Urban sprawl, smart growth, and deliberative democracy. American Journal of Public Health, 100(10), 1852-1856. doi:10.2105/AJPH.2009.182501.

Rohmadiani, L. D., Kunce, Y. A., \& Rachmawanti, I. D. (2020). Fenomena urban sprawl wilayah pembangunan Gresik Selatan. Jurnal Penataan Ruang, 15(1), 1-6. doi:10.12962/j2716179X.v15i1.6722.

Saputra, I. A., Rahmawati, R., \& Listiqowati, I. (2019). Urban sprawl in Palu City. Tadulako Sciencetech Journal, $1(1), 12-25$.

Tappu, A. T. (2014). Pengaruh transformasi spasial terhadap pemanfaatan lahan pertanian di kawasan peri urban Kota Makassar (Kelurahan Barombong). UIN Alauddin Makassar.

Wagistina, S., \& Antariksa, A. (2019). Urban sprawl and residential segregation in Western Suburb Area of Malang City, East Java, Indonesia. Jurnal Pendidikan Geografi, 24(1), 11-24. doi:10.17977/um017v24i12019p011.

Wahyuningsih, N. T., Citra, I. P. A., \& Christiawan, P. I. (2017). Transformasi sosio - spasial berbasis pariwisata di Desa Temukus. Jurnal Pendidikan Geografi Undiksha, 5(2), 72-79. doi:10.23887/jjpg.v5i2.20663. 